\title{
Effect of Natural Aging of Biochar on Soil Enzymatic Activity and Physicochemical Properties in Long-Term Field Experiment
}

\author{
Barbara Futa $^{1}\left(\mathbb{0}\right.$, Patryk Oleszczuk $^{2}$, Sylwia Andruszczak ${ }^{3}$ (D) Ewa Kwiecińska-Poppe ${ }^{3}$ (i) \\ and Piotr Kraska ${ }^{3, *(\mathbb{D})}$ \\ 1 Laboratory of Soil Biology, Institute of Soil Science and Environment Management, University of Life \\ Sciences in Lublin, Leszczyńskiego 7, 20-069 Lublin, Poland; barbara.futa@up.lublin.pl \\ 2 Department of Environmental Chemistry, University of Maria Skłodowska-Curie, Pl. M. \\ Curie-Skłodowskiej 3, 20-031 Lublin, Poland; patryk.oleszczuk@poczta.umcs.lublin.pl \\ 3 Department of Herbology and Plant Cultivation Techniques, University of Life Sciences in Lublin, \\ Akademicka 13, 20-950 Lublin, Poland; sylwia.andruszczak@up.lublin.pl (S.A.); \\ ewa.kwiecinska@up.lublin.pl (E.K.-P.) \\ * Correspondence: piotr.kraska@up.lublin.pl; Tel.: +48-81-445-67-78
}

Received: 19 February 2020; Accepted: 23 March 2020; Published: 24 March 2020

\begin{abstract}
The effect of different rates of biochar on selected soil properties and enzymatic activity 48,60 , and 72 months after biochar application to soil was investigated. Soil enzymatic activity (dehydrogenase-ADh; phosphatase-Aph; urease-AU), the organic carbon content (TOC), the total nitrogen content $\left(\mathrm{N}_{\mathrm{t}}\right)$, the mineral nitrogen content $\left(\mathrm{NH}_{4}{ }^{+}, \mathrm{NO}_{3}{ }^{-}\right)$, and soil $\mathrm{pH}$ were determined. The study was conducted on Haplic Podzol originating from glaciofluvial fine-grained loamy sand. Biochar was applied to soil under winter rye (Secale cereale L.) at rates of $10\left(\mathrm{BC}_{10}\right), 20\left(\mathrm{BC}_{20}\right)$, and $30 \mathrm{tha}^{-1}\left(\mathrm{BC}_{30}\right)$. Plots with biochar-unamended soil were the control treatment $\left(\mathrm{BC}_{0}\right)$. The $\mathrm{pH}, \mathrm{TOC}$, and $\mathrm{N}_{\mathrm{t}}$ content in the biochar-amended soil were higher compared to the control soil. A broader $\mathrm{C}: \mathrm{N}$ ratio was found in the $\mathrm{BC}_{0}$ soil compared to $\mathrm{BC}_{10}, \mathrm{BC}_{20}$, and $\mathrm{BC}_{30}$. With increasing biochar rate, the content of the ammonium nitrogen form $\left(\mathrm{NH}_{4}{ }^{+}\right)$decreased and was statistically lower than in the control soil $\left(\mathrm{BC}_{0}\right)$. The soil in the $\mathrm{BC}_{20}$ and $\mathrm{BC}_{30}$ treatments was characterized by the highest content of $\mathrm{NO}_{3}{ }^{-}$, whereas the lowest nitrate nitrogen content was found in the control soil $\left(\mathrm{BC}_{0}\right)$. Biochar application increased soil enzymatic activity. Dehydrogenase activity increased with increasing biochar rate. As far as phosphatase and urease activity is concerned, a similar relationship was not observed. In this case, the soil amended with biochar at a rate of $20 \mathrm{tha}^{-1}\left(\mathrm{BC}_{20}\right)$ was characterized by the highest phosphatase and urease activity.
\end{abstract}

Keywords: biochar; enzymatic activity; nitrogen forms; Secale cereale; monoculture

\section{Introduction}

Biochar is a product of thermal decomposition of an organic substance in the process of pyrolysis during which, in the absence of oxygen and at a temperature of $300-1000{ }^{\circ} \mathrm{C}$, products such as oil, synthetic gas, and biochar are formed. Biochar, depending on the substrate from which it was produced and on the conditions in which the pyrolysis process is carried out, has different properties [1-4]. Due to its high organic carbon content, well-developed porosity, and specific surface area, biochar can be used to improve properties of agriculturally used soils [5-8]. It increases soil water-holding capacity and $\mathrm{pH}$, prevents nutrient leaching, and binds organic and inorganic contaminants [9]. Biochar can be an element that binds the active substances of plant protection products and heavy metals [10-13]. On account of its high ion exchange capacity, biochar is characterized by the ability to retain and 
exchange soil nutrients [14]. It also contains macro- and micronutrients that are a valuable source of minerals for soil microorganisms, which in consequence stimulates soil microbial activity [15-19]. Nevertheless, biochar can contain contaminants in the form of both heavy metals and polycyclic aromatic hydrocarbons [20].

Soil microorganisms determine the quality of soil environment and belong to its most active components. The activity of enzymes released into the soil environment is an indicator of their metabolic capacity [21,22]. Soil enzyme activity can effectively indicate soil biological activity and nutrient supply capacity, which can reflect soil ecosystem stability and soil health. Enzymes are involved in many biochemical processes in soils, such as organic matter decomposition, carbon (C) mineralization, and C, N, and P cycles [21-24]. Enzymatic processes manifest disturbances in matter cycling and the flow of energy through ecosystem elements. Research reveals that some enzymatic tests reliably reflect the impact of agronomic practices on soil ecological status [21,22,25-28].

In recent years, a lot of attention has been given to research on the use of biochar to improve soil chemical, physical, and biological properties [3,4,11,29-31]. However, there is sparse information on the effect of biochar on soil enzymatic activity and mineral nitrogen content in the arable layer of soil. Existing research has shown that biochar increases soil enzymatic activity. This is a beneficial phenomenon because it indicates proper soil microbiological processes [11]. Biochar application provides an additional source of carbon and nutrients, as well as enhanced sorption properties, probably stimulating the activity of the investigated enzymes [26]. Nonetheless, existing studies have focused on relatively short periods of time. The literature lacks information how biochar affects soil enzymatic activity, in particular in the long term (several years). It is known that, due to the aging process, biochar undergoes different changes that can have a significant impact not only on soil properties, but also on biological life. The research hypothesis assumes that biochar added to soil will change selected physicochemical and biological properties of soil. The aim of the present study was to determine the effect of different biochar rates on soil enzymatic activity, mineral nitrogen, TOC, and $\mathrm{pH}$ over a period of several years after biochar amendment.

\section{Materials and Methods}

\subsection{Biochar Characteristics}

Biochar applied to soil was provided by Mostostal Sp. z o.o. (Wrocław, Poland). Biochar was produced by process of pyrolysis from wheat straw at temperature $650{ }^{\circ} \mathrm{C}$ (maximum applied temperature) in an oxygen-poor atmosphere $\left(<2 \% \mathrm{O}_{2}\right)$. Biochar made from wheat straw was in the form of ash. The biochar was intentionally produced for the purposes of the experiment. To produce 1 $t$ of biochar from wheat straw, $3 t$ of straw must be burned in the pyrolysis process [32]. The chemical properties of biochar were determined by standard methods. The $\mathrm{pH}$ was measured potentiometrically in $1 \mathrm{M} \mathrm{KCl}$ after $24 \mathrm{~h}$ in the liquid/soil ratio of 10 . The available potassium, phosphorus, and magnesium were determined according to procedures for soil analysis [29]. Total organic carbon (TOC) was determined by TOC-VCSH (Shimadzu) with Solid Sample Module SSM-5000. The total nitrogen $(\mathrm{Nt})$ was determined by the Kjeldahl's method without the application of Dewarda's alloy (Cu-Al-Zn alloy reducer of nitrites and nitrates) [33].

The physicochemical characteristics of biochar were as follows: $\mathrm{pH}$ (in $\mathrm{KCl}$ ) 9.9, available forms of phosphorous (P), $235.6 \mathrm{mg} \mathrm{kg}^{-1}$; potassium (K), $2344.6 \mathrm{mg} \mathrm{kg}^{-1}$; and magnesium (Mg), $163.2 \mathrm{mg}$ $\mathrm{kg}^{-1}$. Elemental composition was: $53.87 \% \mathrm{C}, 0.91 \% \mathrm{~N}$, and $1.76 \% \mathrm{H}$. The ratio of hydrogen to carbon was 0.033 , and the ash content was $41.2 \%$. The scanning electron microscope (SEM) pictures of biochar are presented in Figure 1. Pictures show typical features of biochar used in the study-large specific surface area and porosity. 


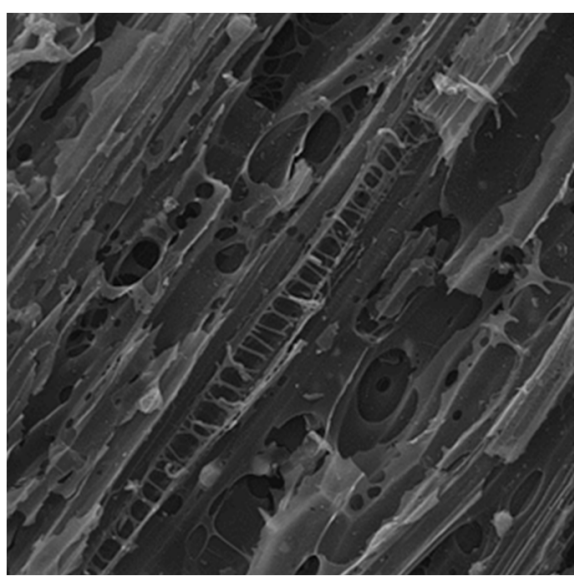

SEM HV: $30.00 \mathrm{kV} \quad$ WD: $10.31 \mathrm{~mm}$

View field: $433.5 \mu \mathrm{m}$ Det: $S E$ SEM MAG: $500 x$
Date(m/d/y): 09/11/15

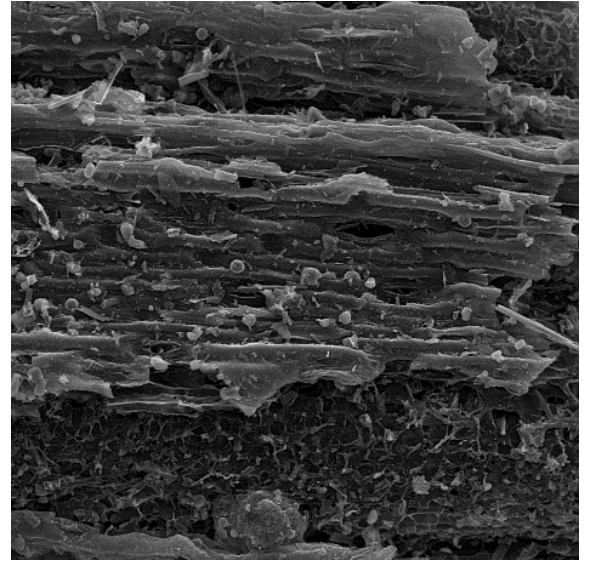

SEM HV: $30.00 \mathrm{kV} \quad$ WD: $9.786 \mathrm{~mm}$

View field: $433.1 \mu \mathrm{m}$ Det: SE

SEM MAG: $500 \times \quad$ Date(m/d/y): 09/11/15

Figure 1. Scanning electron microscope (SEM) pictures of biochar used in the field experiment.

\subsection{Weather Conditions}

Weather conditions were described on the background of the multiyear period 1974-2010 based on the average monthly air temperature $\left({ }^{\circ} \mathrm{C}\right)$ and total precipitation $(\mathrm{mm})$. Additionally, hydrothermal Sielianinov coefficient $(\mathrm{K})$ was calculated according to the formula: $\mathrm{K}=(\mathrm{P} \cdot 10) /(\mathrm{T} \cdot \mathrm{L})$, where $\mathrm{P}$ is the total monthly precipitation, $\mathrm{T}$ is the average monthly temperature, and $\mathrm{L}$ is number of days in the month [34]. In the 2014-2015 season, the total rainfall was only 77\% of the long-term average (Figure 2). The highest rainfall deficits occurred in the period from September to November and also from July to August. During these months, the total rainfall was lower than the long-term average for the relevant period by $30 \%$ and $65 \%$, respectively. The Sielianinov hydrothermal coefficients confirmed that these months were very dry and extremely dry (Table 1). The 2015-2016 season was very humid, since during this season the total rainfall was higher than the long-term average by $31 \%$. The months of September and July were most abundant in rainfall, and the total rainfall in these months was about $60 \%$ higher than to the long-term average. In the third year of the experiment, the total rainfall was similar to the long-term average; however, the distribution of precipitation in individual months varied. The highest amount of rainfall was recorded in October, in which the sum of precipitation was three times higher than the long-term average. At the same time, the highest rainfall deficit was found in the months of September, June, and August. During these months, the total rainfall was only 19\%, $35 \%$, and $56 \%$ of the long-term average, respectively. The average air temperature during the field experiment was above the long-term average for most of the months. In subsequent seasons the air temperature exceeded the long-term average by $2.0^{\circ} \mathrm{C}, 2.2^{\circ} \mathrm{C}$, and $1.0^{\circ} \mathrm{C}$ respectively.

Table 1. Sielianinov hydrothermal coefficients $(\mathrm{K})$ during the growing seasons in the years of the experiment according to the Meteorological Station at Bezek.

\begin{tabular}{ccccccc}
\hline Year & III & IV & V & VI & VII & VIII \\
\hline 2015 & 2.73 & 1.47 & 4.75 & 0.30 & 0.70 & 0.10 \\
2016 & 4.49 & 2.40 & 1.23 & 1.23 & 2.20 & 0.94 \\
2017 & 1.79 & 2.66 & 1.67 & 0.50 & 1.66 & 0.65 \\
\hline
\end{tabular}

Extremely dry, $\mathrm{K} \leq 0.4$; very dry, $0.4<\mathrm{K} \leq 0.7$; dry $0.7,<\mathrm{K} \leq 1.0$; quite dry, $1.0<\mathrm{K} \leq 1.3$; optimal, $1.3<\mathrm{K} \leq 1.6$; quite humid, $1.6<\mathrm{K} \leq 2.0$; humid, $2.0<\mathrm{K} \leq 2.5$; very humid, $2.5<\mathrm{K} \leq 3.0$; extremely humid, $\mathrm{K}>3.0$. 

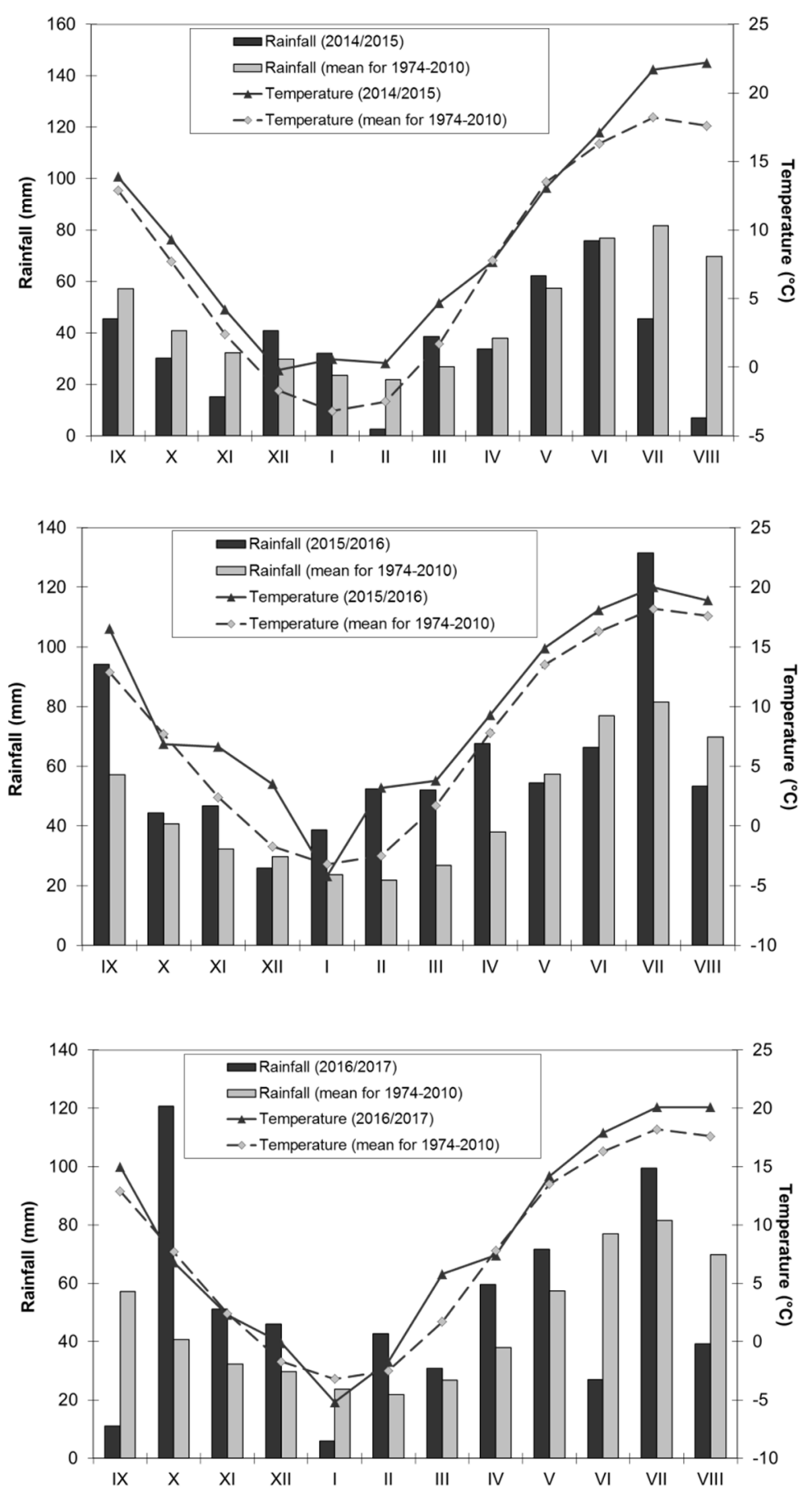

Figure 2. Rainfall and air temperature as compared to the long-term mean figures (1974-2010) according to the Meteorological Station at Bezek.

\subsection{Experimental Site}

The field study was established in 2011 at the Experimental Farm in Bezek ( $\left.51^{\circ} 19^{\prime} \mathrm{N}, 23^{\circ} 25^{\prime} \mathrm{E}\right)$, Poland. The experiment was established on a Haplic Podzol (PZha) originating from glaciofluvial fine-grained loamy sand [35]. The particle size distribution of arable layer of this soil was as follows: $2.0-0.5 \mathrm{~mm}$ fraction $-9 \% ; 0.5-0.25 \mathrm{~mm}$ fraction $-26 \%$; $<0.002 \mathrm{~mm}$ fraction- $2 \%$ [31]. The average amount of $\mathrm{P}$ in the soil was $59.4 \mathrm{mg} \mathrm{kg}^{-1} ; \mathrm{K}-108.5 \mathrm{mg} \mathrm{kg}^{-1} ; \mathrm{Mg}-12.8 \mathrm{mg} \mathrm{kg}^{-1} ; \mathrm{Cu}-1.8 \mathrm{mg} \mathrm{kg}^{-1}$; $\mathrm{Zn}-5.4 \mathrm{mg} \mathrm{kg}^{-1}$; $\mathrm{Mn}-116.1 \mathrm{mg} \mathrm{kg}^{-1} ; \mathrm{Fe}-481.3 \mathrm{mg} \mathrm{kg}^{-1}$; $\mathrm{B}-0.82 \mathrm{mg} \mathrm{kg}^{-1}$; the $\mathrm{pH}$ in $\mathrm{KCl}$ was 5.32 [29]. The experiment, set up in a randomized block design in three replicates, compared the 
effect of three biochar rates in the cultivation of winter rye (Secale cereale L., 'Dańkowskie Diament') cultivated in a monoculture. The area of a single plot was $18 \mathrm{~m}^{2}$. At the beginning of September 2011, biochar at rates of $10\left(\mathrm{BC}_{10}\right), 20\left(\mathrm{BC}_{20}\right)$, and $30\left(\mathrm{BC}_{30}\right)$ t per hectare was applied to the soil, and then the soil was ploughed. The plot without biochar was the control treatment $\left(\mathrm{BC}_{0}\right)$. The spacing between plots fertilized with the different rates of biochar was $2 \mathrm{~m}$. Winter rye was sown every year in the fourth week of September.

The crop was sown at a rate of 5 million seeds per hectare at $12 \mathrm{~cm}$ inter-row spacing. Mineral fertilizers were applied every year of the experiment at the following rates: $70 \mathrm{~kg} \mathrm{ha}^{-1} \mathrm{~N}$ (ammonium nitrate), $26 \mathrm{~kg} \mathrm{ha}^{-1} \mathrm{P}$ (triple superphosphate), and $66 \mathrm{~kg} \mathrm{ha}^{-1} \mathrm{~K}$ (muriate of potash, $\mathrm{KCl}$ ). Phosphorus and potassium fertilizers as well as $20 \mathrm{~kg} \mathrm{ha}^{-1} \mathrm{~N}$ were applied before sowing. In the spring, the remaining portion of the nitrogen $(\mathrm{N})$ rate was applied before plant growth began $\left(30 \mathrm{~kg} \mathrm{ha}^{-1}\right)$ and at the stem elongation stage $\left(20 \mathrm{~kg} \mathrm{ha}^{-1}\right)$. The winter rye crop protection program included the application of the herbicide Aminopielik Tercet 500 SL (2,4-D $300 \mathrm{~g} \mathrm{~L}^{-1}$, Mecoprop $160 \mathrm{~g} \mathrm{~L}^{-1}$, and Dicamba $40 \mathrm{~g} \mathrm{~L}^{-1}$ ) at a rate of $2 \mathrm{~L} \mathrm{ha}^{-1}$ (BBCH 23-29). Moreover, the fungicide Tango Star $334 \mathrm{SE}$ (Fenpropimorph $250 \mathrm{~g} \mathrm{~L}^{-1}$ and Epoxiconazole $84 \mathrm{~g} \mathrm{~L}^{-1}$ ) was applied at a rate of $1 \mathrm{~L} \mathrm{ha}^{-1}$ (BBCH 51-56).

\subsection{Sample Collection}

Soil samples were collected from the 0-25 cm layer in August 2015, 2016, and 2017 (after 48, 60, and 72 months from the beginning of the experiment). The composite soil sample was an average from 15 subsamples taken from each treatment. Individual samples from specific plots were averaged and physicochemical and biochemical properties were determined in these samples in three simultaneous replicates. Tables 1 and 2 also give the values of evaluated parameters as means independent of biochar rates. These data were calculated as means for $\mathrm{BC}_{0}, \mathrm{BC}_{10}, \mathrm{BC}_{20}$, and $\mathrm{B}_{30}$ after 48,60 , and 72 months after biochar incorporation to soil.

\subsection{Enzymatic Activity and Physicochemical Properties}

The enzymatic activities that play an important role in the transformation of organic carbon compounds (dehydrogenases), nitrogen compounds (ureases), and phosphorus compounds (phosphatases) were determined in the soil samples. Activity of dehydrogenases (ADh) was determined by Thalmann's method [36] using a 1\% solution of TTC (triphenyl tetrazolium chloride) as a substrate, expressing their activity in mg 1,3,5-triphenyl formazan (TPF) $\mathrm{kg}^{-1} 24 \mathrm{~h}^{-1}$. Determination of neutral phosphatase activity (APh) was performed according to Tabatabai and Bremner [37] using a $0.8 \%$ sodium p-nitrophenyl phosphate solution as a substrate in buffer $\mathrm{pH}$ 7.0. The APh were expressed in mmol p-nitrophenol (PNP) $\mathrm{kg}^{-1} \mathrm{~h}^{-1}$. Urease activity (AU) was determined following Zantua and Bremner [38] using a 2.5\% urea solution as a substrate, expressing the activity in $\mathrm{mg} \mathrm{N}-\mathrm{NH}_{4}{ }^{+} \mathrm{kg}^{-1} \mathrm{~h}^{-1}$. The content of organic carbon, total nitrogen, and ammonium and nitrate nitrogen were determined according to ISO 14235 [39], ISO 13878 [40], and ISO 14255 [41], respectively. The $\mathrm{pH}$ was measured potentiometrically in $1 \mathrm{M} \mathrm{KCl}$ [42].

\subsection{Data Analysis}

Statistica PL 13.3 (TIBCO Software Inc., Tulsa, OK, USA) was used to conduct ANOVA analysis, and Tukey's mean separation was used to determine statistical significance at $p<0.05$.

\section{Results and Discussion}

\subsection{Physicochemical Properties}

The biochar-amended soil was characterized by higher $\mathrm{pH}$ compared to control soil. The $\mathrm{pH}$ increased with increasing of biochar rate (Table 2). The reason for the increase in soil $\mathrm{pH}$ due to biochar application could be the high surface area and porous nature of biochar, which increases the cation 
exchange capacity (CEC) of the soil by reducing the leaching of base cations in competition with $\mathrm{H}^{+}$ ions $[4,43]$.

The increase of soil $\mathrm{pH}$ after biochar application may be also related to ash content, which contains carbonates of alkali and alkaline earth elements, variable amounts of heavy metals, silica, sesquioxides, phosphates, and small amounts of organic and inorganic nitrogen [44,45]. These results confirmed earlier studies $[4,11,29,46]$ where the increase of soil $\mathrm{pH}$ after biochar application was also observed. Furthermore, this study demonstrated that, over time, soil $\mathrm{pH}$ decreased in the biochar-treated plots, which is also a typical phenomenon in such cases related to the aging of biochar [4].

Table 2. Soil $\mathrm{pH}$, total organic carbon (TOC), total nitrogen (Nt) and mineral form of nitrogen $\left(\mathrm{N}-\mathrm{NH}_{4}{ }^{+}\right.$ and $\mathrm{N}_{-} \mathrm{NO}_{3}{ }^{-}$) contents, and $\mathrm{C}: \mathrm{N}$ ratio in soil after 48, 60, and 72 months from biochar incorporation.

\begin{tabular}{|c|c|c|c|c|c|c|c|}
\hline \multirow{2}{*}{$\begin{array}{c}\text { Assessment } \\
\text { Date/Year }\end{array}$} & \multirow{2}{*}{ Biochar Rate } & \multirow{2}{*}{$\mathrm{p} \mathrm{H}_{\mathrm{KCl}}$} & TOC & $\mathbf{N}_{\mathrm{t}}$ & \multirow{2}{*}{$\mathrm{C}: \mathbf{N}$} & $\mathrm{N}-\mathrm{NH}_{4}{ }^{+}$ & $\mathrm{N}-\mathrm{NO}_{3}{ }^{-}$ \\
\hline & & & \multicolumn{2}{|c|}{$\mathrm{g} \mathrm{kg}^{-1}$} & & \multicolumn{2}{|c|}{$\mathrm{mg} \mathrm{kg}^{-1}$} \\
\hline \multirow{4}{*}{ After 48 months } & $\mathrm{BC}_{0}$ & $5.38 \mathrm{a}$ & $5.95 \mathrm{a}^{*}$ & $0.47 \mathrm{a}$ & $12.75 \mathrm{a}$ & $16.17 \mathrm{a}$ & $57.53 \mathrm{a}$ \\
\hline & $\mathrm{BC}_{10}$ & $6.76 \mathrm{~b}$ & $6.32 \mathrm{~b}$ & $0.56 \mathrm{~b}$ & $11.35 \mathrm{~b}$ & $13.67 \mathrm{~b}$ & $69.24 b$ \\
\hline & $\mathrm{BC}_{20}$ & $6.85 \mathrm{~b}$ & $7.41 \mathrm{c}$ & $0.64 \mathrm{c}$ & $11.52 \mathrm{~b}$ & $10.54 \mathrm{c}$ & $80.81 \mathrm{c}$ \\
\hline & $\mathrm{BC}_{30}$ & $7.15 \mathrm{c}$ & $7.59 \mathrm{~d}$ & $0.69 \mathrm{~d}$ & $11.05 \mathrm{c}$ & $9.16 \mathrm{~d}$ & $77.62 \mathrm{~d}$ \\
\hline \multirow{4}{*}{ After 60 months } & $\mathrm{BC}_{0}$ & $5.37 \mathrm{a}$ & $5.94 \mathrm{a}$ & $0.46 \mathrm{a}$ & $12.91 \mathrm{a}$ & $11.68 \mathrm{a}$ & $74.81 \mathrm{a}$ \\
\hline & $\mathrm{BC}_{10}$ & $6.38 \mathrm{~b}$ & $6.48 \mathrm{~b}$ & $0.63 \mathrm{~b}$ & $10.32 b$ & $9.30 \mathrm{~b}$ & $90.44 b$ \\
\hline & $\mathrm{BC}_{20}$ & $6.65 \mathrm{~b}$ & $7.42 \mathrm{c}$ & $0.68 c$ & $10.99 \mathrm{c}$ & $4.59 \mathrm{c}$ & $101.32 \mathrm{c}$ \\
\hline & $\mathrm{BC}_{30}$ & $6.73 \mathrm{~b}$ & $7.79 \mathrm{~d}$ & $0.71 \mathrm{~d}$ & $10.90 \mathrm{c}$ & $3.01 \mathrm{~d}$ & $92.85 \mathrm{~d}$ \\
\hline \multirow{4}{*}{ After 72 months } & $\mathrm{BC}_{0}$ & $5.40 \mathrm{a}$ & $5.93 \mathrm{a}$ & $0.47 \mathrm{a}$ & $12.63 \mathrm{a}$ & $10.86 \mathrm{a}$ & $121.29 \mathrm{a}$ \\
\hline & $\mathrm{BC}_{10}$ & $5.72 \mathrm{~b}$ & $6.56 \mathrm{~b}$ & $0.65 b$ & $10.02 \mathrm{~b}$ & $8.65 \mathrm{~b}$ & $131.31 \mathrm{~b}$ \\
\hline & $\mathrm{BC}_{20}$ & $5.99 \mathrm{c}$ & $7.78 \mathrm{c}$ & $0.70 \mathrm{c}$ & $11.17 \mathrm{c}$ & $3.94 \mathrm{c}$ & $190.89 \mathrm{c}$ \\
\hline & $\mathrm{BC}_{30}$ & $6.16 \mathrm{~d}$ & $7.88 \mathrm{c}$ & $0.74 \mathrm{~d}$ & $10.68 \mathrm{~d}$ & $2.07 \mathrm{~d}$ & $142.89 \mathrm{~d}$ \\
\hline After 48 months & \multirow{3}{*}{\multicolumn{2}{|c|}{ Average for biochar rates }} & $6.82 \mathrm{a}$ & $0.59 \mathrm{a}$ & $11.58 \mathrm{a}$ & $12.38 \mathrm{a}$ & $71.30 \mathrm{a}$ \\
\hline After 60 months & & & $6.91 \mathrm{a}$ & $0.62 b$ & $11.28 \mathrm{a}$ & $7.14 b$ & $89.86 \mathrm{~b}$ \\
\hline After 72 months & & & $7.04 \mathrm{a}$ & $0.64 \mathrm{c}$ & $11.00 \mathrm{a}$ & $6.38 \mathrm{~b}$ & $146.60 \mathrm{c}$ \\
\hline
\end{tabular}

After 48, 60, and 72 months after biochar application to soil, the total organic carbon (TOC) and total nitrogen $(\mathrm{Nt})$ in the biochar-amended soil were significantly higher than in the control $\left(\mathrm{BC}_{0}\right)$ (Table 1). The soil content of these nutrients was found to increase with increasing biochar rate. The highest values of TOC in the biochar-treated soils indicate the recalcitrance of organic $\mathrm{C}$ in biochar. High TOC and Nt in biochar-amended soil have been similarly reported by a number of authors $[29,43,47]$. In successive years of the study, TOC showed statistically insignificant fluctuations. In turn, the content of Nt behaved differently compared to TOC in biochar-amended soil. Nt increased over the experimental period, which could have been due to the fact that biochar is characterized by the ability to retain and exchange soil nutrients [14]. The values of the C:N ratio in the control soil were shown to be significantly wider than in the soil with biochar addition. In successive growing seasons, the C:N ratio did not change significantly $(p \leq 0.05)$ (Table 2$)$. The $\mathrm{N}^{-\mathrm{NH}_{4}}{ }^{+}$content was the highest in the control soil and gradually decreased in the treatments with the increased biochar rate. At 48 months after biochar application, the $\mathrm{N}^{-N_{4}}{ }_{4}{ }^{+}$content was higher than after 60 and 78 months (Table 2). Biochar amendment caused a significant $(p \leq 0.05)$ increase of the nitrate nitrogen $\left(\mathrm{N}^{-\mathrm{NO}_{3}}{ }^{-}\right)$. The highest content of $\mathrm{N}^{-\mathrm{NO}_{3}}{ }^{-}$over the entire study period was observed for the soil where biochar was applied at a rate of $20 \mathrm{tha}^{-1}$. A significantly lower $\mathrm{N}^{-N_{3}}{ }_{3}^{-}$content was determined in the experiment $\mathrm{BC}_{30}$, while the lowest was determined in the experiment $\mathrm{BC}_{10}$ (Table 2). Biochar application to the soil modifies the nitrogen cycle in the environment. As a soil amendment, biochar exhibits the ability to store nitrogen by reducing the leaching of $\mathrm{N}^{-\mathrm{NO}_{3}}{ }^{-}$ions and also by inducing the growth of nitrogen-fixing bacteria [48-50]. Lehman et al. [15] observed greater activity of microorganisms participating in soil nitrogen fixation already after application of $10 \mathrm{t} \mathrm{ha}^{-1}$ biochar. 


\subsection{Dehydrogenase Activity}

In the biochar treatments, dehydrogenase activity (ADh) was higher than in the control soil. The ADh increased significantly with increasing biochar rate. Moreover, in successive years of observation, ADh decreased to a small extent, regardless of the biochar rate (Table 3). Błońska et al. [51] suggested that decrease of ADh with time may be related to the grown conditions (monoculture) and affects activity of the microorganisms. ADh is a very sensitive indicator of soil property changes and is related to living microbial cells [26,51,52]. Oleszczuk et al. [11] found an increase in ADh in the treatments where biochar was applied at 30 and $45 \mathrm{t} \mathrm{ha}^{-1}$. Sopeña and Bending [53] also indicated the protective role of biochar with regard to ADh. Brzezińska and Włodarczyk [54], in turn, demonstrated a close relationship between ADh and organic matter content, soil fertility, soil microbe numbers, proteolytic activity, nitrification, denitrification, respiration (release of $\mathrm{CO}_{2}$, absorption of $\mathrm{O}_{2}$ ), and also the activity of other enzymes present in the soil environment. The above observations show that the effect of biochar on ADh varies and can take different directions, probably depending on the type of biochar (properties, origin), soil type, or environmental conditions.

Table 3. Enzymatic activity of soils after 48, 60, and 72 months from biochar incorporation.

\begin{tabular}{ccccc}
\hline Assessment Date/Year & Biochar Rate & ADh & APh & AU \\
\hline \multirow{4}{*}{ After 48 months } & $\mathrm{BC}_{0}$ & $1.99 \mathrm{a}^{*}$ & $81.27 \mathrm{a}$ & $2.86 \mathrm{a}$ \\
& $\mathrm{BC}_{10}$ & $3.66 \mathrm{~b}$ & $92.63 \mathrm{~b}$ & $3.43 \mathrm{~b}$ \\
& $\mathrm{BC}_{20}$ & $4.12 \mathrm{c}$ & $97.42 \mathrm{c}$ & $4.42 \mathrm{c}$ \\
& $\mathrm{BC}_{30}$ & $7.30 \mathrm{~d}$ & $95.38 \mathrm{~d}$ & $4.32 \mathrm{c}$ \\
\hline \multirow{3}{*}{ After 60 months } & $\mathrm{BC}_{0}$ & $1.66 \mathrm{a}$ & $59.44 \mathrm{a}$ & $2.36 \mathrm{a}$ \\
& $\mathrm{BC}_{10}$ & $3.07 \mathrm{~b}$ & $60.37 \mathrm{~b}$ & $2.88 \mathrm{~b}$ \\
& $\mathrm{BC}_{20}$ & $3.38 \mathrm{c}$ & $81.01 \mathrm{c}$ & $4.28 \mathrm{c}$ \\
& $\mathrm{BC}_{30}$ & $5.17 \mathrm{~d}$ & $65.41 \mathrm{~d}$ & $3.43 \mathrm{~d}$ \\
\hline \multirow{3}{*}{ After 72 months } & $\mathrm{BC}_{0}$ & $1.25 \mathrm{a}$ & $43.03 \mathrm{a}$ & $2.05 \mathrm{a}$ \\
& $\mathrm{BC}_{10}$ & $2.80 \mathrm{~b}$ & $49.21 \mathrm{~b}$ & $2.32 \mathrm{~b}$ \\
\hline After 48 months & $\mathrm{BC}_{20}$ & $3.29 \mathrm{c}$ & $59.32 \mathrm{c}$ & $2.98 \mathrm{c}$ \\
After 60 months & $\mathrm{BC}_{30}$ & $5.04 \mathrm{~d}$ & $53.81 \mathrm{~d}$ & $2.51 \mathrm{~d}$ \\
After 72 months & & $4.27 \mathrm{a}$ & $91.67 \mathrm{a}$ & $3.76 \mathrm{a}$ \\
\hline
\end{tabular}

$\mathrm{ADh}$-dehydrogenases in mg TPF kg-1 $24 \mathrm{~h}^{-1} ; \mathrm{APh}$ - phosphatase in mmol PNP kg-1 $\mathrm{h}^{-1} ; \mathrm{AU}$ - urease in mg $\mathrm{N}-\mathrm{NH}_{4}{ }^{+} \mathrm{kg}^{-1} \mathrm{~h}^{-1}$; * different letters indicate significant difference at $p \leq 0.05 ; \mathrm{BC}_{0}$ - plots without biochar (control treatment); $\mathrm{BC}_{10}$-biochar rate of $10 \mathrm{tha}^{-1} ; \mathrm{BC}_{20}$-biochar rate of $20 \mathrm{tha}^{-1} ; \mathrm{BC}_{30}$-biochar rate of $30 \mathrm{t} \mathrm{ha}^{-1}$.

\subsection{Phosphatase Activity}

Phosphatases play an important role in soil, stimulating organic transformations of phosphorus compounds into inorganic phosphates $\left(\mathrm{HPO}_{4}{ }^{-2}\right.$ and $\left.\mathrm{H}_{2} \mathrm{PO}_{4}{ }^{-}\right)$which are directly available to plants and soil organisms [55]. Phosphatase activity ( $\mathrm{APh}$ ) in the soil environment reflects the activity of enzymes associated with soil colloids and humic substances, free phosphatases in the soil solution, and phosphatases associated with living and dead plant cells and microorganisms [56]. APh can be a good indicator of the organic phosphorus mineralization potential and soil biological activity [57]. The highest $\mathrm{APh}$ was found in the soil amended with biochar at $20 \mathrm{tha}^{-1}$, which was significantly $(p \leq 0.05)$ higher compared to 30 and $10 \mathrm{t} \mathrm{ha}^{-1}$. On the other hand, the control soil was characterized by lowest phosphatase activity (Table 3). Gong et al. [58] found that biochar applied at low rates $(<1 \%)$ can increase the enzymatic activity of soil microbes. Over the experimental period, APh was found to decrease. According to Gregorich et al. [59], periodic changes in enzyme activity are associated with changes in soil moisture content and oxygenation, and they do not depend on small differences in soil $\mathrm{C}$ and $\mathrm{N}$ content. In the study period presented, the monthly rainfall totals were very variable, 
whereas the mean air temperatures exceeded the long-term mean, which could have influenced the observed changes in APh (Figure 2).

\subsection{Urease Activity}

Ureases catalyze the hydrolysis of urea in soil to carbon dioxide and ammonium. These enzymes are found in cells of many higher plants and microorganisms, in particular bacteria [60]. According to Vaheda et al. [61], soil urease activity (AU) correlates with TOC and Nt content. These authors also noted a significant relationship between urease activity and soil $\mathrm{N}-\mathrm{NH}_{4}{ }^{+}$content. Similarly, in the present study, both TOC and Nt content and $\mathrm{AU}$ were highest in the treatments where the highest biochar rates $\left(\mathrm{BC}_{20}\right.$ and $\left.\mathrm{BC}_{30}\right)$ were applied. The highest $\mathrm{AU}$ was found in the same treatments where the $\mathrm{N}^{-\mathrm{NO}_{3}}{ }^{-}$content was the highest (Tables 2 and 3). In each successive growing season, $\mathrm{AU}$ decreased. This could have been attributable to the decline in soil properties due to monoculture cropping of rye and also to the effect of biochar aging. Attention is drawn to this phenomenon by Gul et al. [4], who found that the properties of biochar change due to its aging in soil, in particular on account of its oxidation and the accumulation of $\mathrm{H}^{+}$from the soil solution. In turn, Natywa et al. [62] found the respiratory activity of monoculture soils to decrease compared to those where crop rotation was used. Vahed et al. [61] report that for AU the optimum value of $\mathrm{pH}$ is between 6 and 7. Hence, this was probably the reason for the lower AU in the third year of the experiment, in which a slightly lower soil $\mathrm{pH}$ was found in all studied treatments compared to the earlier period (Tables 2 and 3).

\section{Conclusions}

Application of biochar to the soil resulted in a significant increase of TOC and Nt as well as $\mathrm{N}_{-\mathrm{NO}_{3}}{ }^{-}$. In comparison to the control soil, the $\mathrm{C}: \mathrm{N}$ ratio and the $\mathrm{N}-\mathrm{NH}_{4}{ }^{+}$content decreased. The biochar-amended soil showed higher ADh, APh, and AU. However, when analyzing soil enzymatic activity, it was found that $\mathrm{ADh}, \mathrm{APh}$, and AU were increasingly lower in successive years of the study, regardless of the biochar rate, which was probably associated with the effect of biochar aging and monoculture cropping of rye. The present study clearly confirms that it is possible to use biochar to improve soil biological activity, in particular during the initial period after biochar application. Its positive impact on enzymatic activity is limited and weakens as a result of biochar aging. Soil enzymatic activity should therefore be monitored, and after several years biochar should be applied again, which in consequence will result in an increase in the soil's biological activity.

Author Contributions: P.O., P.K., B.F., and S.A. conceptualized the research; P.K., B.F., and S.A. designed the research; P.K., S.A., and E.K.-P. Performed the experiments; B.F., P.O., and P.K. analyzed the data; B.F., P.K., P.O., and S.A. wrote the paper. All authors have read and agreed to the published version of the manuscript.

Funding: This research was funded by the Ministry of Science and Higher Education, Poland.

Conflicts of Interest: This research was funded by the Ministry of Science and Higher Education, Poland. The authors declare no conflict of interest. The funders had no role in the design of the study; in the collection, analyses or interpretation of data; in the writing of the manuscript, or in the decision to publish the results.

\section{References}

1. Steinbeiss, S.; Gleixner, G.; Antonietti, M. Effect of biochar amendment on soil carbon balance and soil microbial activity. Soil Biol. Biochem. 2009, 41, 1301-1310. [CrossRef]

2. Bruun, E.W.; Ambus, P.; Egsgaard, H.; Hauggaard-Nielsen, H. Effects of slow and fast pyrolysis biochar on soil C and N turnover dynamics. Soil Biol. Biochem. 2012, 46, 73-79. [CrossRef]

3. Ameloot, N.; Sleutel, S.; Das, K.C.; Kanagaratnam, J.; De Neve, S. Biochar amendment to soils with contrasting organic matter level: Effects on N mineralization and biological soil properties. GCB Bioenergy 2015, 7, 135-144. [CrossRef]

4. Gul, S.; Whalen, J.K.; Thomas, B.W.; Sachdeva, V.; Deng, H. Physico-chemical properties and microbial responses in biochar-amended soils: Mechanisms and future directions. Agric. Ecosyst. Environ. 2015, 206, 46-59. [CrossRef] 
5. Vaccari, F.P.; Baronti, S.; Lugato, E.; Genesio, L.; Castaldi, S.; Fornasier, F.; Miglietta, F. Biochar as a strategy to sequester carbon and increase yield in durum wheat. Eur. J. Agron. 2011, 34, 231-238. [CrossRef]

6. Karer, J.; Wimmer, B.; Zehetner, F.; Kloss, S.; Soja, G. Biochar application to temperate soils: Effects on nutrient uptake and crop yield under field conditions. Agric. Food Sci. 2013, 22, 390-403. [CrossRef]

7. Farrell, M.; Macdonald, L.M.; Butler, G.; Chirino-Valle, I.; Condron, L.M. Biochar and fertiliser applications influence phosphorus fractionation and wheat yield. Biol. Fertil. Soils 2014, 50, 169-178. [CrossRef]

8. Prendergast-Miller, M.T.; Duvall, M.; Sohi, S.P. Biochar-root interactions are mediated by biochar nutrient content and impacts on soil nutrient availability. Eur. J. Soil Sci. 2014, 65, 173-185. [CrossRef]

9. Smebye, A.; Alling, V.; Vogt, R.D.; Gadmar, T.C.; Mulder, J.; Cornelissen, G.; Hale, S.E. Biochar amendment to soil changes dissolved organic matter content and composition. Chemosphere 2016, 142, 100-105. [CrossRef]

10. Cabrera, A.; Cox, L.; Spokas, K.; Hermosín, M.C.; Cornejo, J.; Koskinen, W.C. Influence of biochar amendments on the sorption-desorption of aminocyclopyrachlor, bentazone and pyraclostrobin pesticides to an agricultural soil. Sci. Total Environ. 2014, 470-471, 438-443. [CrossRef]

11. Oleszczuk, P.; Jośko, I.; Futa, B.; Pasieczna-Patkowska, S.; Pałys, E.; Kraska, P. Effect of pesticides on microorganisms, enzymatic activity and plant in biochar amended soil. Geoderma 2014, 214-215, 10-18. [CrossRef]

12. Vithanage, M.; Bandara, T.; Al-Wabel, M.I.; Abduljabbar, A.; Usman, A.R.A.; Ahmad, M.; Sik, O.Y. Soil enzyme activities in waste biochar amended multi-metal contaminated soil; effect of different pyrolysis temperatures and application rates. Commun. Soil Sci. Plan 2018, 49, 635-643. [CrossRef]

13. Wang, J.; Wang, S.H. Preparation, modification and environmental application of biochar: A review. J. Clean. Prod. 2019, 227, 1002-1022. [CrossRef]

14. McHenry, M.P. Agricultural bio-char production, renewable energy generation and farm carbon sequestration in Western Australia: Certainty, uncertainty and risk. Agric. Ecosyst. Environ. 2009, 129, 1-7. [CrossRef]

15. Lehmann, J.; Rilling, M.C.; Thies, J.; Masiello, C.A.; Hockaday, W.C.; Crowley, D. Biochar effects on soil biota-A review. Soil Biol. Biochem. 2011, 43, 1812-1836. [CrossRef]

16. Jones, D.L.; Rousk, J.; Edwards-Jones, G.; DeLuca, T.H.; Murphy, D.V. Biochar- mediated changes in soil quality and plant growth in a three year field trial. Soil Biol. Biochem. 2012, 45, 113-124. [CrossRef]

17. Rutigliano, F.A.; Romano, M.; Marzaioli, R.; Baglivo, I.; Baronti, S.; Miglietta, F.; Castaldi, S. Effect of biochar addition on soil microbial community in a wheat crop. Eur. J. Soil Biol. 2014, 60, 9-15. [CrossRef]

18. Ouyang, L.; Tang, Q.; Yu, L.; Zhang, R. Effects of amendment of different biochars on soil enzyme activities related to carbon mineralization. Soil Res. 2014, 52, 706-716. [CrossRef]

19. Hairani, A.; Osaki, M.; Watanabe, T. Effect of biochar application on mineral and microbial properties of soils growing different plant species. Soil Sci. Plant Nutr. 2016, 62, 519-525. [CrossRef]

20. Oleszczuk, P.; Jośko, I.; Kuśmierz, M. Biochar properties regarding to contaminants content and ecotoxicological assessment. J. Hazard. Mater. 2013, 260, 375-382. [CrossRef]

21. Shukla, G.; Varma, A. (Eds.) Soil Enzymology. In Soil Biology; Springer Science \& Business Media: Berlin, Germany, 2011; Volume 22.

22. Gianfreda, L.; Rao, M.A. (Eds.) Enzymes in Agricultural Sciences; OMICS International: Hyderabad, India, 2014.

23. Caldwell, B.A. Enzyme activities as a component of soil biodiversity: A review. Pedobiologia (Jena) 2005, 49, 637-644. [CrossRef]

24. Makoi, J.H.J.R.; Ndakidemi, P.A. Selected soil enzymes: Examples of their potential roles in the ecosystem. Afr. J. Biotechnol. 2008, 7, 181-191.

25. Piotrowska, A.; Wilczewski, E. Effects of catch crops cultivated for green manure and mineral nitrogen fertilization on soil enzyme activities and chemical properties. Geoderma 2012, 189, 72-80. [CrossRef]

26. Paz-Ferreiro, J.; Gascó, G.; Gutiérrez, B.; Méndez, A. Soil biochemical activities and the geometric mean of enzyme activities after application of sewage sludge and sewage sludge biochar to soil. Biol. Fertil. Soils 2012, 48, 511-517. [CrossRef]

27. Majchrzak, L.; Sawinska, Z.; Natywa, M.; Skrzypczak, G.; Głowicka-Wołoszyn, R. Impact of different tillage systems on soil dehydrogenase activity and spring wheat infection. J. Agric. Sci. Technol. 2016, 18, 1871-1881.

28. Adetunji, A.T.; Lewu, F.B.; Mulidzi, R.; Ncube, B. The biological activities of $\beta$-glucosidase, phosphatase and urease as soil quality indicators: A review. J. Soil Sci. Plant Nutr. 2017, 17, 794-807. [CrossRef] 
29. Kraska, P.; Oleszczuk, P.; Andruszczak, S.; Kwiecińska-Poppe, E.; Różyło, K.; Pałys, E.; Gierasimiuk, P.; Michałojć, Z. Effect of various biochar rates on winter rye yield and the concentration of available nutrients in the soil. Plant Soil Environ. 2016, 62, 483-489. [CrossRef]

30. Kraska, P.; Andruszczak, S.; Oleszczuk, P.; Świeca, M.; Kwiecińska-Poppe, E.; Gierasimiuk, P.; Różyło, K.; Pałys, E. The content of elements and quality parameters of winter rye grain as influenced by biochar-amended soil. Zemdirbyste 2018, 105, 11-20. [CrossRef]

31. Pranagal, J.; Oleszczuk, P.; Tomaszewska-Krojańska, D.; Kraska, P.; Różyło, K. Effect of biochar application on the physical properties of Haplic Podzol. Soil Tillage Res. 2017, 174, 92-103. [CrossRef]

32. Verheijen, F.G.A.; Jeffery, S.; Bastos, A.C.; van der Velde, M.; Diafas, I. Biochar Application to Soils-A Critical Scientific Review of Effects on Soil Properties, Processes and Functions; EUR 24099 EN; Office for the Official Publications of the European Communities: Ispra, Italy, 2010; pp. 1-167.

33. Van Reeuwijk, L.P. Procedures for Soil Analysis; International Soil Reference and Information Centre: Wageningen, The Netherlands, 1992.

34. Skowera, B. Changes of hydrothermal conditions in the polish area (1971-2010). Fragm. Agron. 2014, 31, 74-87.

35. WRB 2014. World Reference base for Soil Resources 2014; World Soil Resources Reports, 106; FAO: Rome, Italy, 2015.

36. Thalmann, A. Zur Methodik derestimmung der Dehydrogenase aktivit in Boden mittels Triphenyltetrazoliumchlorid (TTC). Landwirtsch. Forsch. 1968, 21, 249-258.

37. Tabatabai, M.A.; Bremner, J.M. Use of p-nitrophenol phosphate for assay of soil phosphatase activity. Soil Biol. Biochem. 1969, 1, 301-307. [CrossRef]

38. Zantua, M.I.; Bremner, J.M. Comparison of methods of assaying urease activity in soils. Soil Biol. Biochem. 1975, 7, 291-295. [CrossRef]

39. International Organization for Standardization. Soil Quality. Determination of Organic Carbon by Sulfochromic Oxidation; ISO, 14235; ISO: Geneva, Switzerland, 1998.

40. International Organization for Standardization. Soil Quality. Determination of Total Nitrogen Content by Dry Combustion; ISO, 13878; ISO: Geneva, Switzerland, 1998.

41. International Organization for Standardization. Soil Quality_Determination of Nitrate Nitrogen, Ammonium Nitrogen and Total Soluble Nitrogen in Air-Dry Soils Using Calcium Chloride Solution as Extractant; ISO 14255; ISO: Geneva, Switzerland, 1998.

42. International Organization for Standardization. Soil Quality. Determination of $p H$; ISO, 10390; ISO: Geneva, Switzerland, 2005.

43. Nigussie, A.; Kissi, E.; Misganaw, M.; Ambaw, G. Effect of biochar application on soil properties and nutrient uptake of lettuces (Lactuca sativa) grown in chromium polluted soils. Am. Eurasian J. Agric. Environ. Sci. 2012, 12, 369-376.

44. Raison, R.J. Modification of the soil environment by vegetation fires, with particular reference to nitrogen transformation: A Review. Plant Soil 1979, 51, 73-108. [CrossRef]

45. Solaiman, Z.N.; Anawar, H.M. Application of biochars for soil constraints: Challenge and solutions. Pedosphere 2015, 25, 631-638. [CrossRef]

46. Curaqueo, G.; Meier, S.; Khan, N.; Cea, M.; Navia, R. Use of biochar on two volcanic soils: Effects on soil properties and barley yield. J. Soil Sci. Plant Nutr. 2014, 14, 911-924. [CrossRef]

47. Abrishamkesh, S.; Gorji, M.; Asadi, H.; Bagheri-Marandi, G.H.; Pourbabaee, A.A. Effects of rice husk biochar application on the properties of alkaline soil and lentil growth. Plant Soil Environ. 2015, 61, 475-482. [CrossRef]

48. Anderson, C.R.; Condron, L.M.; Clough, T.J.; Fiers, M.; Stewart, A.; Hill, R.A.; Sherlock, R.R. Biochar induced soil microbial community change: Implications for biogeochemical cycling of carbon, nitrogen and phosphorus. Pedobiologia 2011, 54, 309-320. [CrossRef]

49. Clough, T.; Condron, L. Biochar and the Nitrogen Cycle: Introduction. J. Environ. Qual. 2010, 39, 1218-1223. [CrossRef]

50. Clough, T.; Condron, L.; Kammann, C.; Müller, C. A review of biochar and soil nitrogen dynamics. Agronomy 2013, 3, 275-293. [CrossRef]

51. Błońska, E.; Lasota, J.; Zwydak, M. The relationship between soil properties, enzyme activity and land use. For. Res. Pap. 2017, 78, 39-44. [CrossRef] 
52. Gałązka, A.; Gawryjołek, K.; Perzyński, A.; Gałązka, R.; Księżak, J. Changes in Enzymatic Activities and Microbial Communities in Soil under Long-Term Maize Monoculture and Crop Rotation. Pol. J. Environ. Stud. 2017, 26, 39-46. [CrossRef]

53. Sopeña, F.; Bending, G.D. Impacts of biochar on bioavailability of the fungicide azoxystrobin: A comparison of the effect on biodegradation rate and toxicity to the fungal community. Chemosphere 2013, 91, 1525-1533. [CrossRef] [PubMed]

54. Brzezińska, M.; Włodarczyk, T. Enzymes of intracellular redox trasformations (Oxidoreductases). Acta Agrophysica Rozprawy i Monografie 2005, 3, 11-26.

55. Bielińska, E.J. Methods of determination of photosphatase activity. Acta Agrophysica Rozprawy i Monografie 2005, 3, 63-74.

56. Nannipieri, P.; Grego, S.; Ceccanti, B. Ecological Significance of the Biological Activity in Soil. In Soil Biochemistry; Bollag, J.M., Stotzky, G., Eds.; Marcek Dekker: New York, NY, USA, 1990; Volume 6, pp. 293-355.

57. Dick, W.A.; Tabatabai, M.A. Significance and Potential Uses o Soil Enzymes. In Soil Microbial Ecology: Application in Agricultural and Environmental Management; Metting, F.B., Ed.; Marcel Dekker: New York, NY, USA, 1993; pp. 95-125.

58. Gong, X.; Huang, D.; Liu, Y.; Zeng, G.; Chen, S.; Wang, R.; Xu, P.; Cheng, M.; Zhang, C.; Xue, W. Biochar facilitated the phytoremediation of cadmium contaminated sediments: Metal behavior, plant toxicity, and microbial activity. Sci. Total Environ. 2019, 666, 1126-1133. [CrossRef]

59. Gregorich, E.G.; Caster, M.R.; Augers, D.A.; Monreal, C.M.; Ellest, B.H. Towards a minimum data set to asses soil organic matter quality in agricultural soils. Can. J. Soil Sci. 1994, 74, 367-385. [CrossRef]

60. Bremner, J.M.; Douglas, L.A. Inhibition of urease activity in soils. Soil Biol. Biochem. 1971, 3, $297-307$. [CrossRef]

61. Vahed, H.S.; Shahinrokhsar, P.; Rezaei, M. Influence of some soil properties and temperature on urease activity in Wetland Rice soils. Am. Eurasian J. Agric. Environ. Sci. 2011, 11, 310-313.

62. Natywa, M.; Selwet, M.; Maciejewski, T. Effect of some agrotechnical factors on the number and activity soil microorganisms. Fragm. Agron. 2014, 31, 56-63.

(C) 2020 by the authors. Licensee MDPI, Basel, Switzerland. This article is an open access article distributed under the terms and conditions of the Creative Commons Attribution (CC BY) license (http://creativecommons.org/licenses/by/4.0/). 